\title{
Study on Deformation Law of Deep Foundation Pit with the Top-Down Method and Its Influence on Adjacent Subway Tunnel
}

\author{
Yue Gui $\left(D,{ }^{1}\right.$ Zhenxing Zhao, ${ }^{1}$ Xiaqiang Qin, ${ }^{2}$ and Jianfei Wang ${ }^{3}$ \\ ${ }^{1}$ Department of Civil Engineering, Kunming University of Science and Technology, Kunming 650504, Yunnan, China \\ ${ }^{2}$ China Mcc20 Group Corp. Ltd., Shanghai 201900, China \\ ${ }^{3}$ Yunnan Construction and Investment Holding Group CO., Ltd., Kunming 650504, Yunnan, China
}

Correspondence should be addressed to Yue Gui; gydrgui@kmust.edu.cn

Received 20 August 2020; Revised 12 October 2020; Accepted 11 November 2020; Published 1 December 2020

Academic Editor: Peixin Shi

Copyright ( 92020 Yue Gui et al. This is an open access article distributed under the Creative Commons Attribution License, which permits unrestricted use, distribution, and reproduction in any medium, provided the original work is properly cited.

\begin{abstract}
Based on a long-term comprehensive instrumentation program, the performance of an excavation pit constructed by the topdown method in downtown Kunming was extensively examined. The measured excavation responses included the deflections of diaphragm wall, vertical column movement, slab axial force, building settlement caused by ground deformation, and the influence of pit excavation on the adjacent subway tunnel. This paper analyses the monitoring data of the existing construction stage. Based on the analyses on the data of field and numerical simulation, the following major findings were obtained: (1) the relationship between the measured maximum wall deflection, $\delta_{h m}$, and excavation depth, $H$, in this study is $\delta_{h m}=0.06 \% H \sim 0.27 \% H$, which is quite different compared with the relationship of soft-soil pit $\delta_{h m}=0.02 \% H \sim 1.2 \% H$, but closer to the normalized curve of rocksocketed pile $\delta_{h m}=0.01 \% H \sim 0.45 \% H$ and rock-socketed diaphragm wall $\delta_{h m}=0.031 \% H \sim 0.129 \% H$. (2) The relationship between the maximum settlement of column $\left(\delta_{p}\right)$ and excavation depth $(H)$ is $\delta_{p}=-0.09 \% \sim 0.04 \% H$. The maximum distortion between the diaphragm wall and the column is less than 1/500 of the limit range proposed by Bjerrum. (3) The impact range caused by excavation is about 3.8 times the maximum excavation depth. The ground settlement around the foundation pit is groove type, and the maximum settlement point is located at 2.7 times the maximum excavation depth. (4) The excavation of the foundation pit leads to the maximum vertical settlement of $2 \mathrm{~mm}$ and maximum horizontal displacement of $5.2 \mathrm{~mm}$ in the subway tunnel; the maximum change of axial force and bending moment are $8.8 \mathrm{kN}$ (the vertical direction) and $6.4 \mathrm{kN} \cdot \mathrm{m} / \mathrm{m}$ (the horizontal direction), respectively.
\end{abstract}

\section{Introduction}

The top-down method has the advantages of little influence on the surrounding environment and saving construction time. It has been widely used since it was put forward in 1933 by Japanese engineers, and many scholars have studied it. Fan and Zhao [1] put forward the theory of superstructurediaphragm-wall-pile-foundation-foundation interaction, which can calculate the stress and deformation of each section of top-down construction. Tan and $\mathrm{Li}[2,3]$, Liu et al. [4], Xu et al. [5], Hwang Richard et al. [6], Ou et al. [7], Wong et al. [8], and Leung and $\mathrm{Ng}$ [9] combined the engineering case of the top-down method pit to study the deformation law and the influence of pit excavation on the surrounding environment in soft-soil areas (e.g., Shanghai,
Singapore, Hong Kong, and Taipei). Compared with the empirical values put forward by Peck [10], Hsieh and $\mathrm{Ou}$ [11], and Clough and O'Rourke [12], the deformation law of foundation pits with different construction methods in softsoil areas were analyzed, which provides a good reference for the application of the top-down method in soft-soil areas. With the city's development, the traditional down-top method cannot meet the requirements of the surrounding environment, and the top-down method is more widely used. However, the top-down method in Yunnan is in its initial stage, and the related engineering experience is lacking. Because of the different geological conditions, the deformation law of the top-down method pit in different areas is slightly different, and the engineering experience in the soft-soil area has a limited guiding role for the 
engineering in this area. Summarizing the engineering experience in this area can make up for this defect.

With the development of urban rail transit, it is common for a subway tunnel to exist around the pit. The existence of a subway tunnel and foundation pit interact with each other, and the subway tunnel affects the soil stress around the foundation pit. In contrast, the excavation of the foundation pit affects the safety of the subway tunnel. Many scholars have studied it. By analyzing the field monitoring data, Kuang et al. [13] found that the pit's excavation will cause the tunnel to move sideways towards the foundation pit and make the tunnel cross-section deform in the shape of a transverse ellipse. After the foundation slab casts, the tunnel's lateral movement is fundamentally controlled to achieve stability. Chang et al. [14] analyzed the field monitoring data and found that a subway tunnel will reduce the ground displacement caused by pit excavation. The longitudinal direction of the tunnel has a great influence on the deformation bearing value of the tunnel. Based on Mindlin solution, Winkler solution, and Boussinesq solution, Jiang et al. [15], Zhang et al. [16], and Zhang et al. [17] put forward analytical solutions for displacement and internal force changes of surrounding subway tunnels caused by pit excavation and explored the influences of tunnel depth, the horizontal distance between tunnel and pit, outer tunnel diameter, foundation soil, excavation area and excavation sequence on deformation, and internal force of tunnels. Ai et al. [18], Qi et al. [19], Hu et al. [20], Lo and Ramsay [21], Wang et al. [22], and Jiang et al. [23] used a numerical method to explore the influence of different construction schemes and reinforcement measures of foundation pit on surrounding subway tunnels. From the above research, it can be found that theoretical method and numerical method are commonly used research methods, but because of the complexity of foundation pit construction boundary, it is difficult to solve the influence of foundation pit excavation on surrounding environment by theoretical method, and numerical method provides a powerful tool for solving this problem [24].

This study investigated the performance of an $18.5 \mathrm{~m}$ deep excavation pit beside arterial roads, which was constructed by the top-down method and rock-socketed support structure in the commercial district of downtown Kunming, China. Field measurements of the deflections of diaphragm walls, vertical movements of the column, axial forces of the slab, and the building's settlements caused by ground deformation were reported, analyzed, and established; a three-dimensional model by MIDAS/GTS software is used to explore the influence of excavation on subway tunnels. This project provides a reference for the application of the top-down method and the rock-socketed supporting method in Yunnan.

\section{Project Information}

2.1. Project Introduction. This study project is located in downtown Kunming (Figures 1(a)-1(c) show the aerial views of the project). The excavation pit was approximately $113 \mathrm{~m}$ by $170 \mathrm{~m}$ in the plan, and there are four stories of the basement with an excavation depth of $18.5 \mathrm{~m}$. The east side of the pit is Beijing road, the main traffic road to the city. The south side of the pit is the commercial building with 20-floor concrete pile foundation, the bank of the 25-storey reinforced concrete structure with pile foundation is located next to the commercial building and two residential buildings with 7 floors of natural foundation (reference numerals 1 and 2 in Figure 2). There are 17-storey and 34-storey pile foundations, residential buildings, and apartments with frame structure on the north side. On the west side are the community and residential buildings (reference numerals 3-6 in Figure 2) with 7 floors of brick and concrete with a shallow foundation. The investigated excavation consisted of three sections (i.e., the bottom-up excavation sections $\mathrm{A}$ and $\mathrm{B}$ and the top-down excavation section C). Considering (1) limited construction space and (2) mitigation of potentially adverse effects on adjacent buildings and facilities as much as possible, the top-down method was adopted for this deep excavation. Table 1 briefly illustrates the top-down excavation sequence in this study. Unfortunately, for some reasons, after the completion of B2 slab $(10.8 \mathrm{~m})$, some areas were excavated to $12 \mathrm{~m}$, and the foundation pit stopped construction. It started with the construction of a $1 \mathrm{~m}$ thick diaphragm wall. The diaphragm wall was toed through the silty clay layers into the underlying moderately weathered limestone to provide lateral stability and effectively cut off groundwater. The load-bearing elements consisted of augercast-in-place (ACIP) piles, and the diameter is $1 \mathrm{~m}$, which penetrated the strongly weathered limestone layers. Interior H-section steel columns $(460 \mathrm{~mm} \times 460 \mathrm{~mm})$ were constructed on the deep-seated ACIP piles to sustain construction loads and function as permanent structures for later use. After the supporting structure was completed, the bottom-up excavation sections, $\mathrm{A}$ and $\mathrm{B}$, started excavation. When the underground parts of $\mathrm{A}$ and $\mathrm{B}$ completed construction, superstructure construction to 7 th floor, the topdown excavation section $\mathrm{C}$ started excavation. Considering the vast area of section $C$ (about $19210 \mathrm{~m}^{2}$ ) and the facility of unearthed passage, section $\mathrm{C}$ was divided into six regions for excavation to reduce the impact of excavation (as shown in Figure 2). Figure 3 shows the section of $A-A^{\prime}$, which shows the relationship between the foundation pit and the surrounding subway tunnel, the foundation's main structure, and the stratigraphic distribution.

2.2. Geology and Soil Parameters. Before excavation, soil conditions at the site were explored by a series of field exploration programs (e.g., boreholes and standard penetration test). The strata concerned in this project site consisted of seven layers with total depth up to $79.7 \mathrm{~m}$. The first upper layer was an artificial fill, and beneath it was the silt clay layer. The cobble layer, silty clay, and limestone underlie the silt clay. The observed long-term groundwater table at the site was around 0.3 to $0.5 \mathrm{~m}$. The specific information of the main soil layer is shown in Table 2 .

2.3. Instrumentation. A long-term comprehensive instrumentation program was conducted in situ to monitor the deep excavation performance for securing the safety of this project. Figure 4 presents the instrumentation employed to 


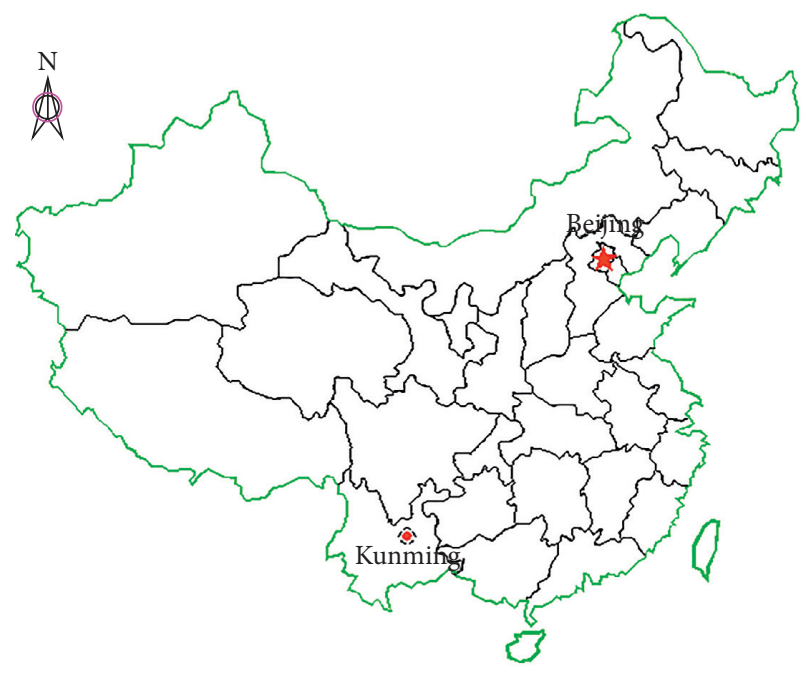

(a)

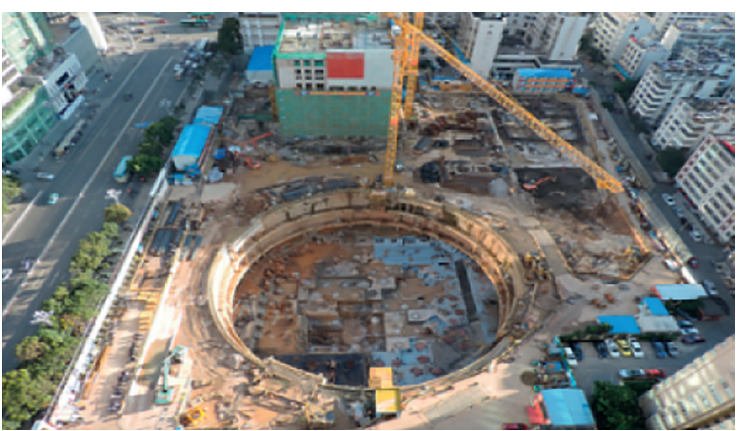

(b)

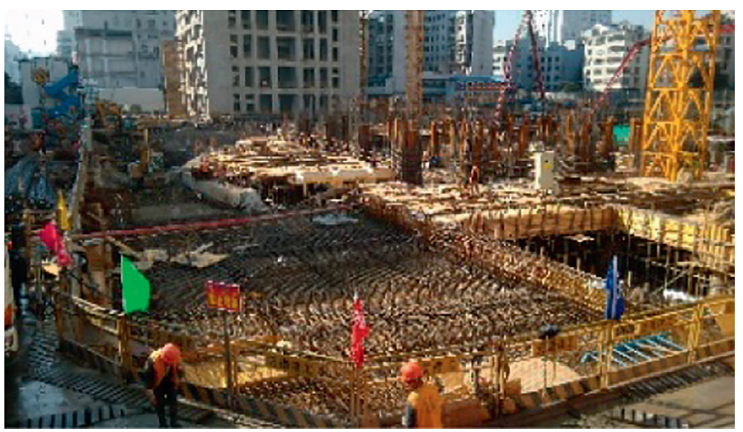

(c)

Figure 1: Site location (a). Aerial views of the project ((b), (c)).

analyze deformation rules. The deflections of the diaphragm walls were monitored by 11 inclinometer tubes (designated as SC1 to SC7 and SC13 to SC16), and the length of the inclinometer is consistent with the height of the diaphragm wall. Vertical column movements were surveyed by a level instrument (C1-C56). Axial forces in floor slabs measured by vibrating wire stress meters which connected with the steel bars in the slab, and the axial force change of the slab is obtained by monitoring the steel bar meter. A level instrument surveyed critical building settlements at 56 locations (D1-D56). Road settlement was observed by a level instrument at 8 sites (L1-L8). There are 12 groundwater tables outside the pit (SW1SW12). To ensure the safety of the subway tunnel, deformation observation points are set on the sidewall and vault of the subway tunnel and monitored by the level instrument. The distance between monitoring points is $20 \mathrm{~m}$, and the distance between monitoring points is reduced to $10 \mathrm{~m}$ in the section with large deformation of foundation pit supporting structure.

\section{Observed Performance of the Excavation}

3.1. Deflections of Diaphragm Walls. When the foundation pit was excavated, the diaphragm wall began to deform under stress. Effective diaphragm wall deflections at SC3, SC4, SC5, and SC14 are summarized in Figures 5(a)-5(d), respectively. The positive and negative values in the diagram represent the diaphragm wall moving outside the pit and inside the pit, respectively. The deflection profiles developed into a bulged profile inward as excavation depth increased, and the locations of maximum wall deflections moved downward as excavation went deeper. Due to the diaphragm wall embedded rock, the deflection is different from the soft-soil; near the bedrock, the deflection is gradually concentrated and decreased; after entering the rock stratum, the deformation of diaphragm wall decreases sharply due to the high stiffness of rock. Instead of the deformation form in soft-soil pit, the deformation of diaphragm wall decreases gradually in soft-soil pit, so there will be obvious inflection point at the rock-soil interface [25]. With the casting of B2 slab, the wall stopped moving towards the excavation site. On the contrary, it moved backward some of the retained sides. It indicates that the $\mathrm{B} 2$ slab can suppress the inward wall deflection movements behind. The deflection of SC7 is significantly smaller than the others because it is very close to the cylindrical shaft of section A. The maximum deflections of SC3 and SC7 located at the short side (SouthNorth) of the foundation pit were $20.8 \mathrm{~mm}$ and $14.5 \mathrm{~mm}$, respectively, which are smaller than the deflections of SC4 $(32.2 \mathrm{~mm})$ and SC14 $(27.2 \mathrm{~mm})$ at the long side of the foundation pit (West-East). The relationship between the measured maximum wall deflection, $\delta_{h m}$, and excavation depth, $H$, is $\delta_{h m}=0.06 \% H \sim 0.27 \% H$, which is quite different from the normalized deformation curve of the existing soft-soil foundation pit $\delta_{h m}=0.02 \% H \sim 1.2 \% H$ [3], and compared with the normalized curve of the rock-socketed supported foundation pit, $\delta_{h m}=0.01 \% H \sim 0.45 \% H$ (rock-socketed pile) [26], and $\delta_{h m}=0.031 \% H \sim 0.129 \% H$ (rock-socketed diaphragm wall) [27] is closer (as shown in Figure 6). The different normalized deformation between the soft-soil pit and rocksocketed supported pit is due to rock and soil's different stiffness. The area, the ratio of length to the fineness, and the form of the supporting structure of pit lead to the difference of normalized range between this study and other rock-socketed supporting foundation pits. 


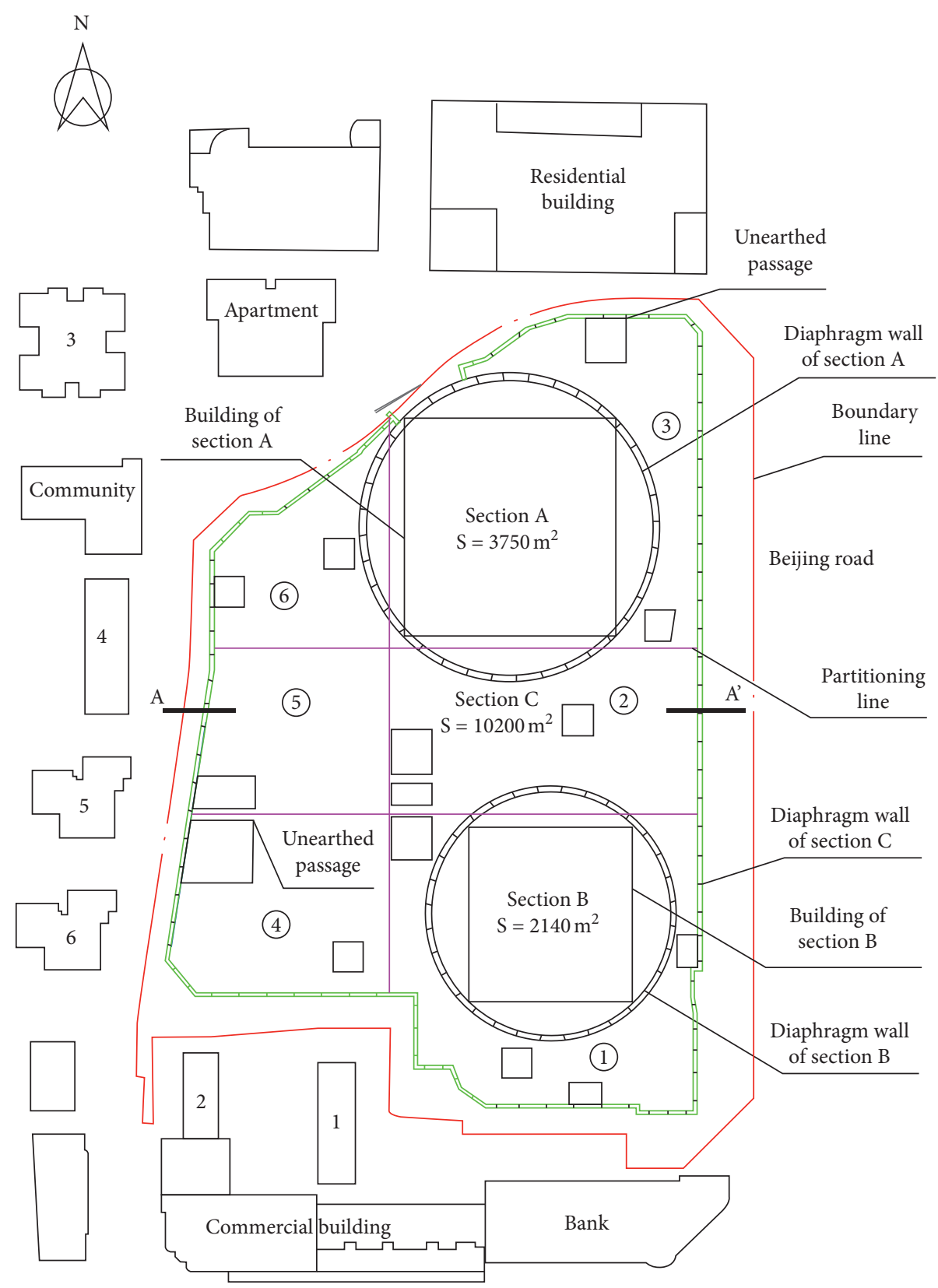

FIgURE 2: Surrounding environment of foundation pit.

TABLE 1: Main construction stages.

\begin{tabular}{lcc}
\hline Stage & Construction operation & Scheduled start date \\
\hline 1 & Construction of the diaphragm wall of section C & $11 / 01 / 2013$ \\
2 & Construction of the ACIP piles of section C, excavation, and construction of sections A and B & $02 / 01 / 2014$ \\
3 & Excavation to a depth of $2.3 \mathrm{~m}$ and casting of slab B0 & $10 / 20 / 2014$ \\
4 & Excavation to a depth of $7.3 \mathrm{~m}$ and casting of slab B1 & $01 / 17 / 2015$ \\
5 & Excavation to a depth of $10.8 \mathrm{~m}$ and casting of slab B2 & $02 / 04 / 2015$ \\
6 & Excavation to a depth of $14.3 \mathrm{~m}$ and casting of slab B3 & $05 / 27 / 2015$ \\
7 & Excavation to a depth of $18.5 \mathrm{~m}$ and casting of the basement slab & $07 / 21 / 2015$ \\
\hline
\end{tabular}

3.2. Vertical Column Movement. In the top-down method, the column's deformation is closely connected with the pit's safety and quality. Following excavation, the column might move upwards or downwards, which depends on basal heaves and vertical loads applied on the column (e.g., the weights of the cast floor slabs, friction force applied by 


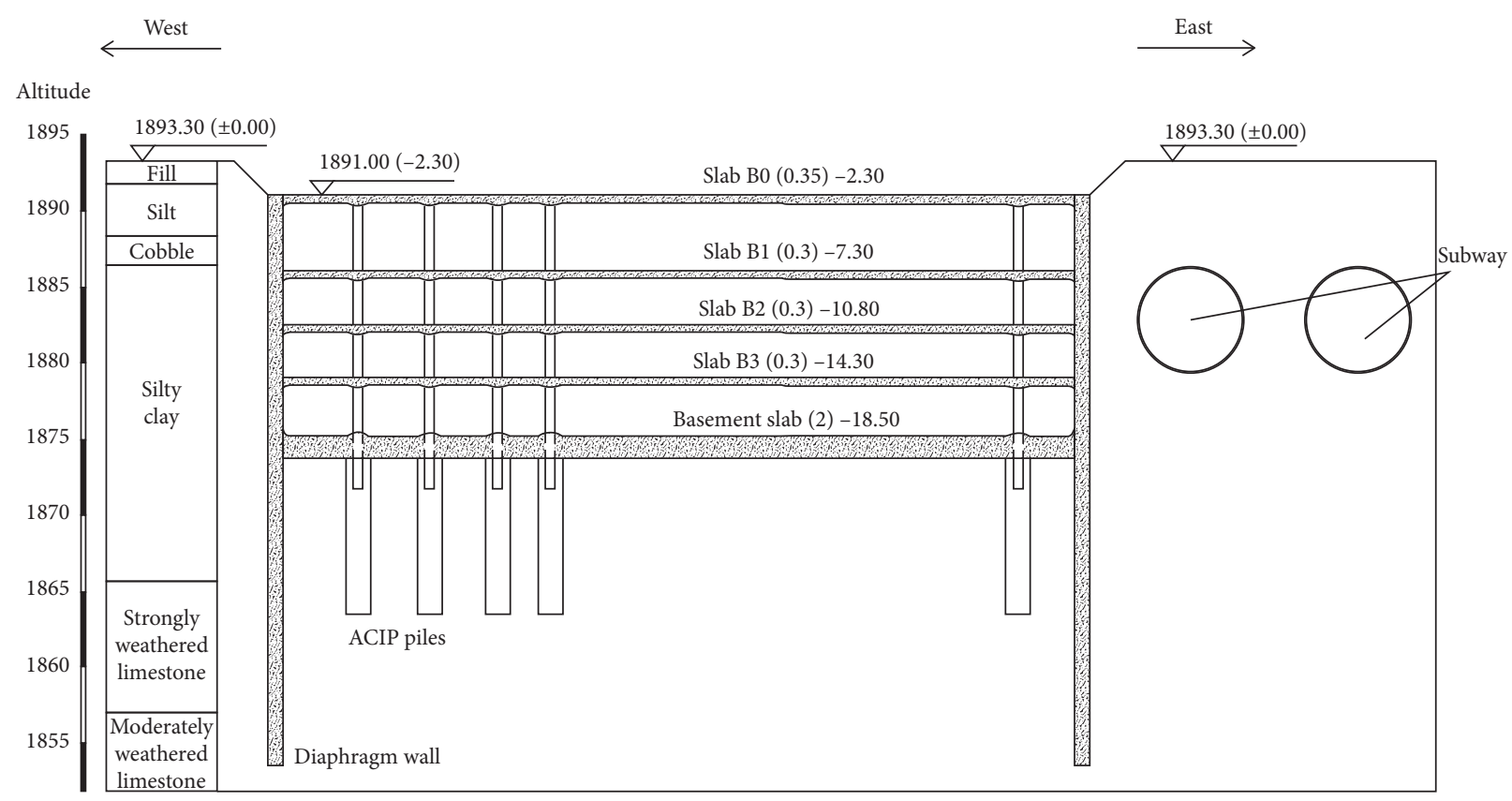

Figure 3: Typical section of A-A'.

TABLE 2: Soil layer information.

\begin{tabular}{|c|c|c|c|c|c|c|c|c|c|}
\hline $\begin{array}{l}\text { Soil layer } \\
\text { number }\end{array}$ & Name of soil & $\begin{array}{l}\text { Depth, } H \\
(\mathrm{~m})\end{array}$ & $\begin{array}{c}\text { Cohesion, } c \\
(\mathrm{kPa})\end{array}$ & $\begin{array}{c}\text { Friction } \\
\text { angle, } \varphi\left(^{\circ}\right)\end{array}$ & $\begin{array}{c}\text { Elastic } \\
\text { modulus, } E \\
(\mathrm{MPa})\end{array}$ & $\begin{array}{l}\text { Poisson } \\
\text { ratio, } \mu\end{array}$ & $\begin{array}{c}\text { Unit } \\
\text { weight, } \gamma \\
\left(\mathrm{kN} / \mathrm{m}^{3}\right)\end{array}$ & SPT & $\begin{array}{c}\text { Saturated uniaxial } \\
\text { compressive } \\
\text { strength }(\mathrm{MPa}) \\
\end{array}$ \\
\hline (1) 2 & Fill & $-1.5 \sim-4.2$ & 18 & 11 & 5 & 0.35 & 18.6 & - & - \\
\hline (2) 1 & Silt & $-2.6 \sim-4.6$ & 8 & 10 & 3 & 0.3 & 18.7 & $3-5$ & - \\
\hline (3) 1 & Cobble & $-2 \sim-5.6$ & - & - & 15 & 0.24 & 27 & - & - \\
\hline (4) 1 & Silty clay & $-5 \sim-16$ & 28 & 10 & 8 & 0.33 & 19.3 & $8-10$ & - \\
\hline (4) 2 & Silty clay & $-11.4 \sim-27.8$ & 28 & 11 & 8 & 0.32 & 19.3 & $12-14$ & - \\
\hline (4) 3 & Silty clay & $-15 \sim-34$ & 30 & 13 & 8.5 & 0.33 & 19.4 & $13-14$ & - \\
\hline (5) 1 & Silty clay & $-3.1 \sim-20$ & 30 & 16 & 10 & 0.3 & 19.6 & $15-17$ & - \\
\hline (6) 1 & $\begin{array}{l}\text { Silty clay } \\
\text { Strongly }\end{array}$ & $-8.3 \sim-27.4$ & 35 & 18 & 11.5 & 0.32 & 19.5 & $16-18$ & - \\
\hline$(7)_{1}$ & $\begin{array}{l}\text { weathered } \\
\text { limestone }\end{array}$ & $-16.5 \sim-61.5$ & - & - & 90 & 0.2 & 26 & - & - \\
\hline $7_{2}$ & $\begin{array}{l}\text { Moderately } \\
\text { weathered } \\
\text { limestone }\end{array}$ & - & - & - & 500 & 0.2 & 30 & - & 93.1 \\
\hline
\end{tabular}

ground soils, construction equipment, and heavy vehicles for material transportation). Figure 7 presents the typical development of the vertical column movements during the construction of stages 3 to 5 . It was noticed that the columns experienced undulated vertical movements throughout the construction. That can interpret this phenomenon during each excavation level. The columns were lifted first by the basal heave due to immediate stress relief (soil removal) and then were pushed downwards under the cast floor slabs' weight. After the casting of B1 slab, the column shows a continuous sinking trend, and the settlement tends to be stable until the casting of B2 slab. It can be seen that the stress release caused by excavation after the casting of B1 slab is less than the weights of the slabs and the construction load, and the settlement does not continue to develop because the foundation pit stops construction after the casting of B2 slab. The ratio of the maximum settlement of the column pile $\delta_{p}$ to the excavation depth $H$ is $\delta_{p}=-0.09 \% \sim 0.04 \% H$. The maximum differential settlement of column pile deformation and diaphragm wall deformation is less than 1/500 of the differential settlement limit value of the supporting structure proposed by Bjerrum in 1963 [28].

3.3. Slab Axial Force. Axial force variations of $\mathrm{B} 0$ slab and $\mathrm{B} 1$ slab during excavation are shown in Figures 8(a) and 8(b), respectively, in which the negative values represent the pressure. The measured axial force in the floor slabs increased during the excavation stage. After casting of the B2 slab, the axial force in the floor slab stabilized. The lateral 


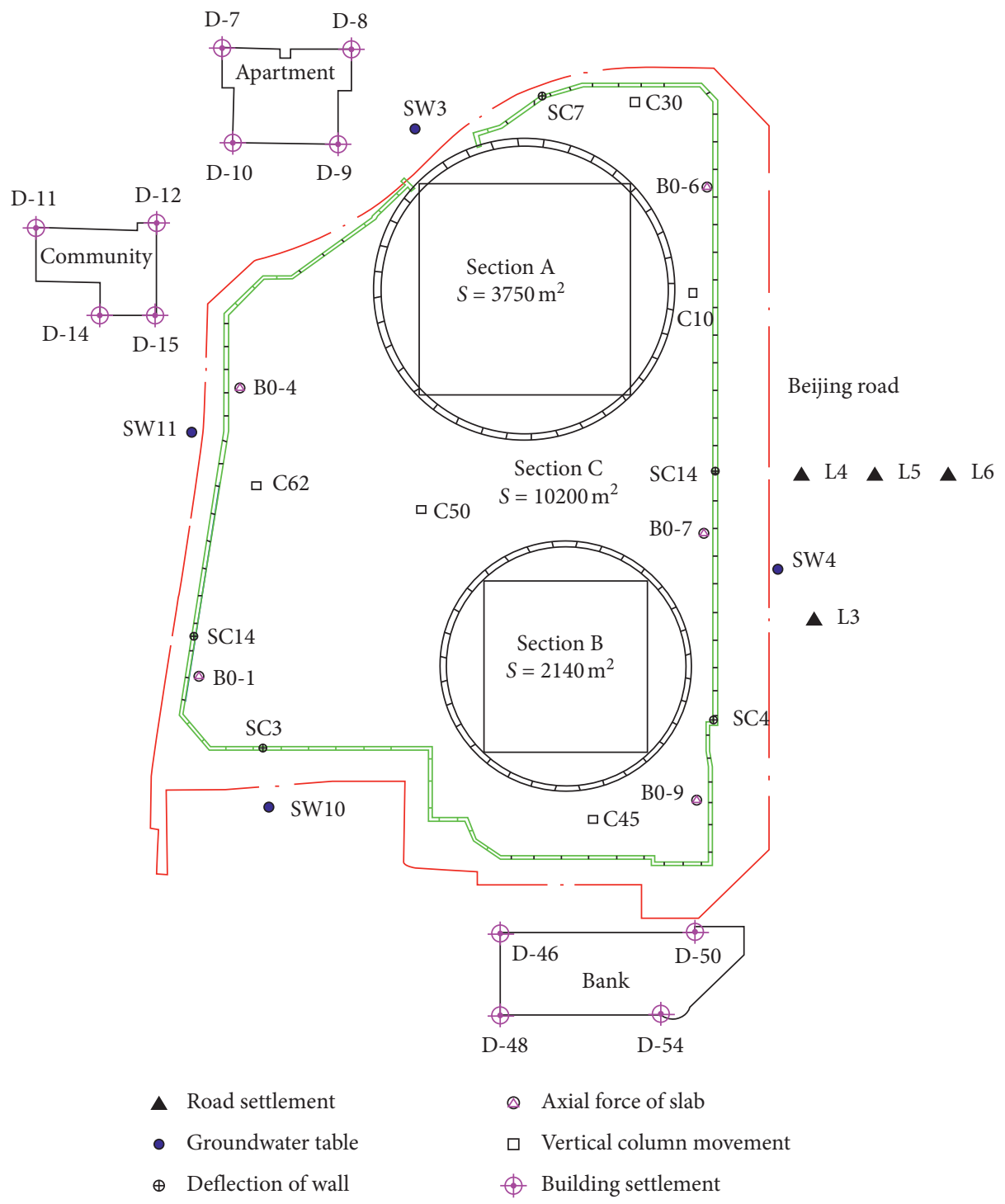

FIgURE 4: Instrumentation layout of the pit.

earth pressures released due to excavation were sustained by the floor slabs above the excavation surfaces, and the deeper excavation has little influence on the axial force of the slab. For example, the maximum axial force change of the B0 slab on the first floor of the basement excavation is $93 \mathrm{kN}$, and with the casting of the B1 slab, the system's stiffness and stability increase, and the axial force tended to be stable. The excavation of the second basement has little effect on it.

3.4. Building Settlement. The settlement of apartment, bank, community, and Beijing road caused by ground deformation during construction is shown in Figures 9(a)-9(d), respectively. The deformation of surrounding buildings at the initial stage of construction shows a fluctuating state. With the casting of the slab, the supporting structure's weight increases, and with the completion of the stage 5 construction, the measured settlement of buildings tends to increase with time.
Figure 10 plots the relationship between the building settlements due to ground settlement, $\delta_{v}$, and distance, $d$, behind the diaphragm wall at the final excavation depth (stage 5), $H_{e}$, for this study, in which $H_{e}$ normalized both $\delta_{v}$ and $d$. The ground settlement in this study showed a typical concave profile, and the maximum ground settlements did not occur right behind the diaphragm wall but in the zones around $2.7 H_{e}$ away. The ground settlement range is mostly located in Zone I of Peck [10], and the maximum value is located in Zone II of Peck [10]. As shown in Figure 10, the normalized $\delta \mathrm{v} / \mathrm{He}$ in this study were same as the subway foundation pit which supported by rock-socketed pile [26], but smaller than the subway foundation pit which is supported by rocksocketed diaphragm wall [27]. The pit's size, the ratio of length to width, supporting structure form, and surrounding environment are the main reasons for these differences.

Figure 11 presents the relationships between the normalized building settlements caused by ground deformation, $\left(\delta_{v} / \delta_{v m}\right)$ and distance ratio $\left(d / H_{e}\right)$, in which $\delta_{v}$ is the 


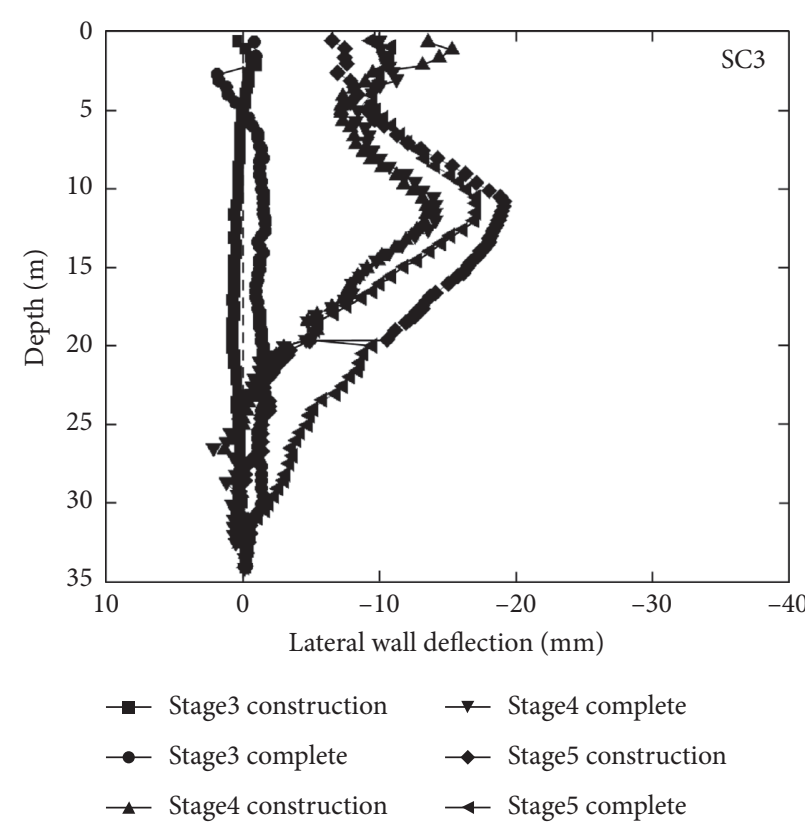

(a)
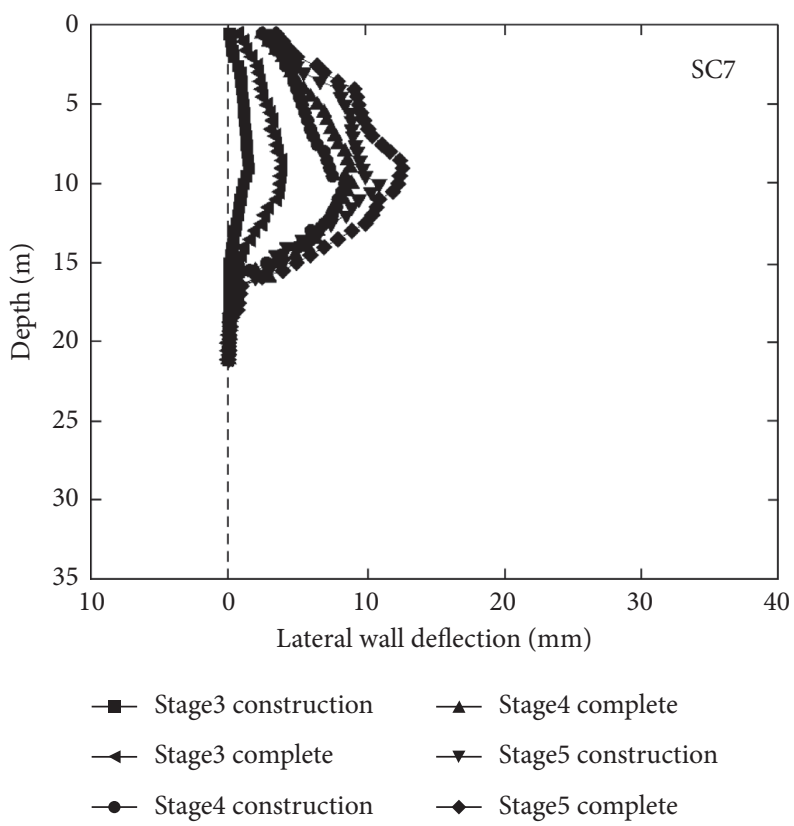

(c)

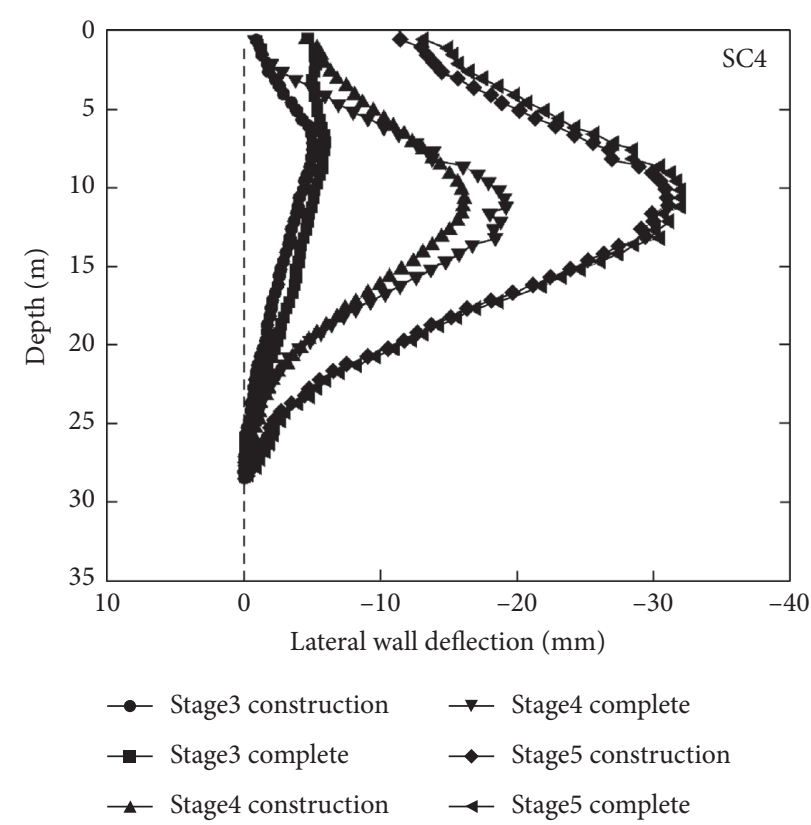

(b)
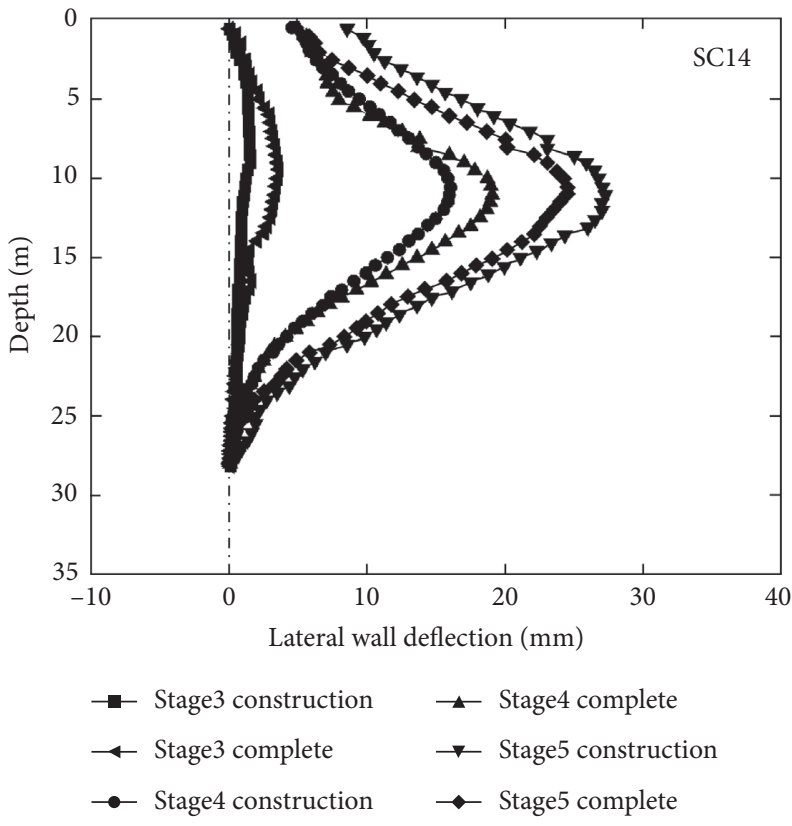

(d)

FIGURE 5: Summary of the effective lateral wall deflections at (a) SC3; (b) SC4; (c) SC7; and (d) SC14.

building settlement at a survey point along the a critical section, and $\delta_{v m}$ is the maximum building settlement at the same section. However, the settlement data of this study had much wider influence zones than those defined by Clough and O'Rourke [12] and Hsieh and Ou [11] and the subway foundation pit which was supported by rock-socketed diaphragm wall (2019) [27] and rock-socketed pile (2015) [29].
The settlement influence zone extended beyond $3.8 \mathrm{H}_{e}$, distant from the pit, but exhibited an apparent tendency of decreasing with distance. The significantly wider distribution of $\left(\delta_{v} / \delta_{v m}\right)$ in this study should mainly derive from its super-large size, which incurred a much bigger displacement of wall deformation and ground settlement and incurred a much wider stress field during excavation. 


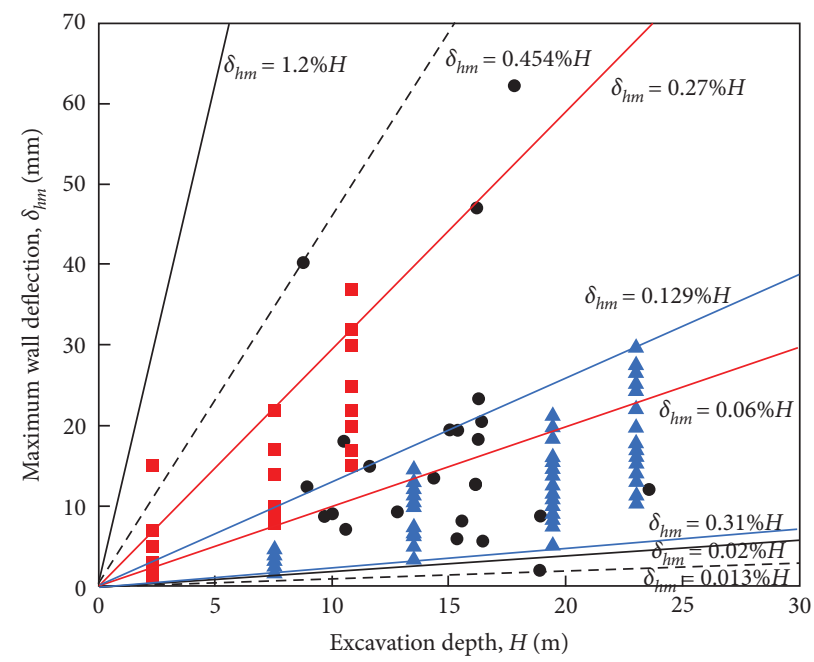

$$
\begin{array}{ll}
\text { - This study } & \text { _ Peck and Yong Tan (soft soil) } \\
\text { - Rock-socketed pile (2018) } & \text { - - - Huang Minghui (2018) } \\
\text { \ } \begin{array}{l}
\text { Rock-socketed diaphragm } \\
\text { wall (2019) }
\end{array} & \text { — Tang Cong (2019) } \\
\text { This study } &
\end{array}
$$

Figure 6: The relationships between $H$ and $\delta_{h m}$.

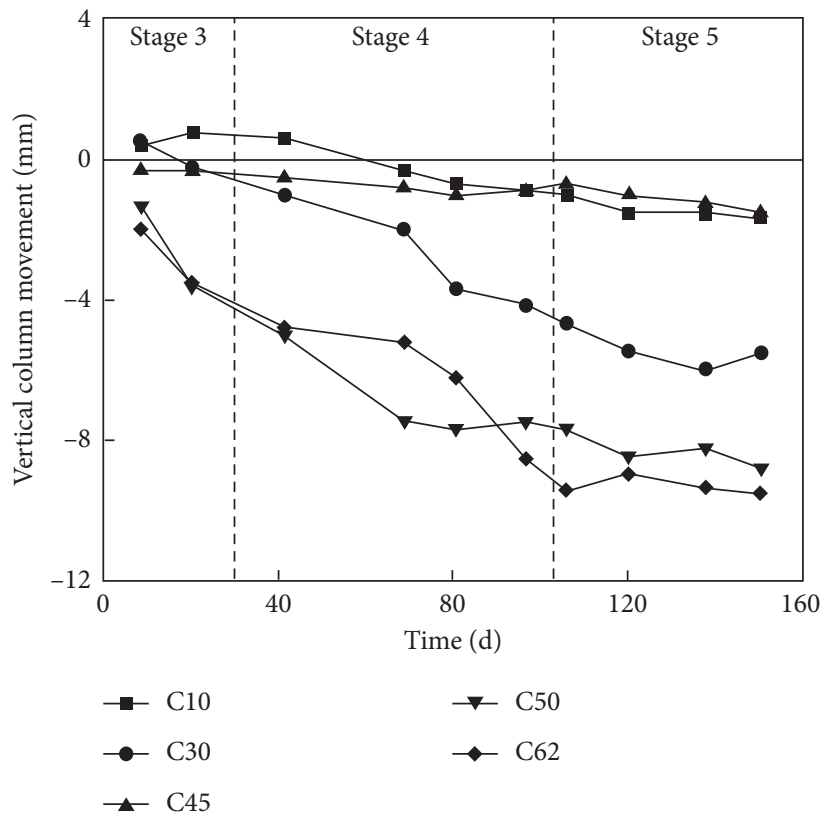

FIgURE 7: Typical vertical column movement.

3.5. Variation of Groundwater Table Level. Figure 12 presents the measured groundwater table levels during construction at SW3, SW4, SW10, and SW11 outside the pit. During the construction, the measured groundwater table levels at SW3, SW4, SW10, and SW11 fluctuated slightly between 0 and $0.5 \mathrm{~m}$ according to seasonal changes, which were within the Kunming areas' long-term groundwater table levels. This proved that the diaphragm walls successfully cut off the water flow during excavation.

\section{Influence on Subway Tunnel}

In this section, the three-dimensional geotechnical finite element MIDAS/GTS software is used to simulate and 

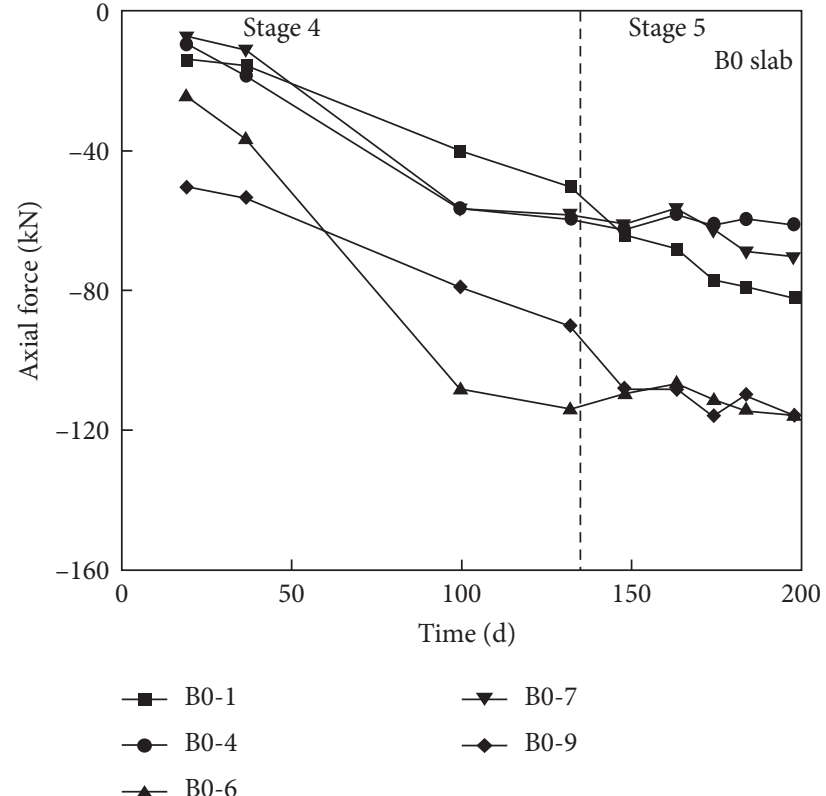

(a)

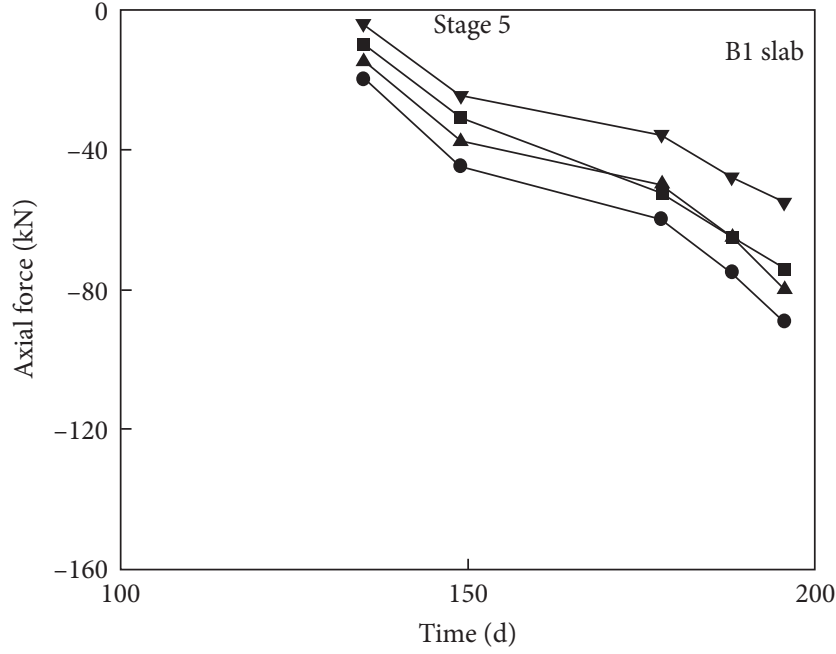

- $\mathrm{B} 1-1$

$\triangle \mathrm{B} 1-3$

$\rightarrow$ B1-6

Figure 8: Typical slab axial force. (a) B0 slab; (b) B1 slab.

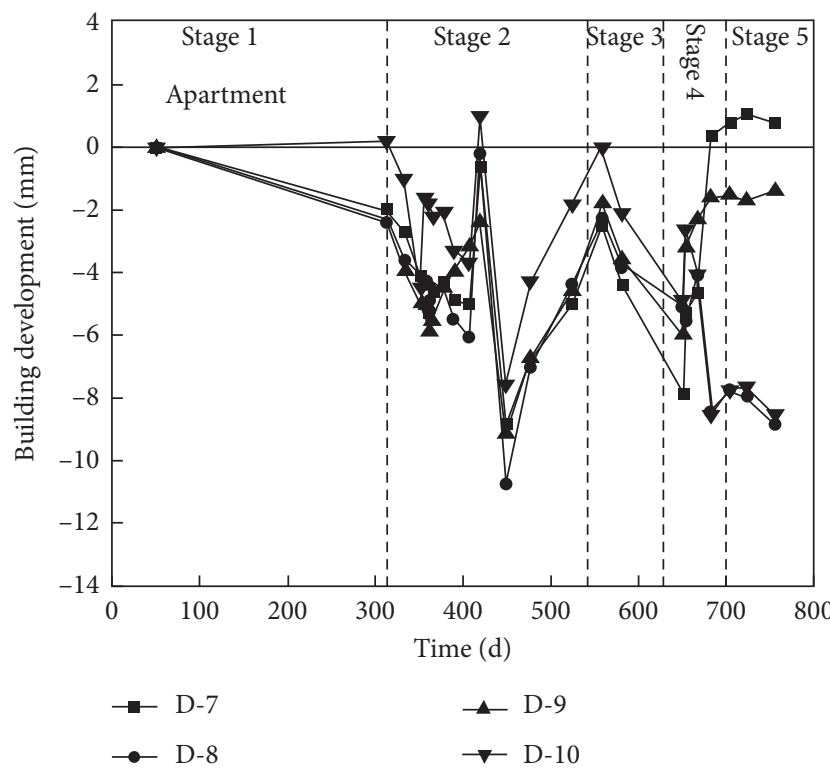

(a)

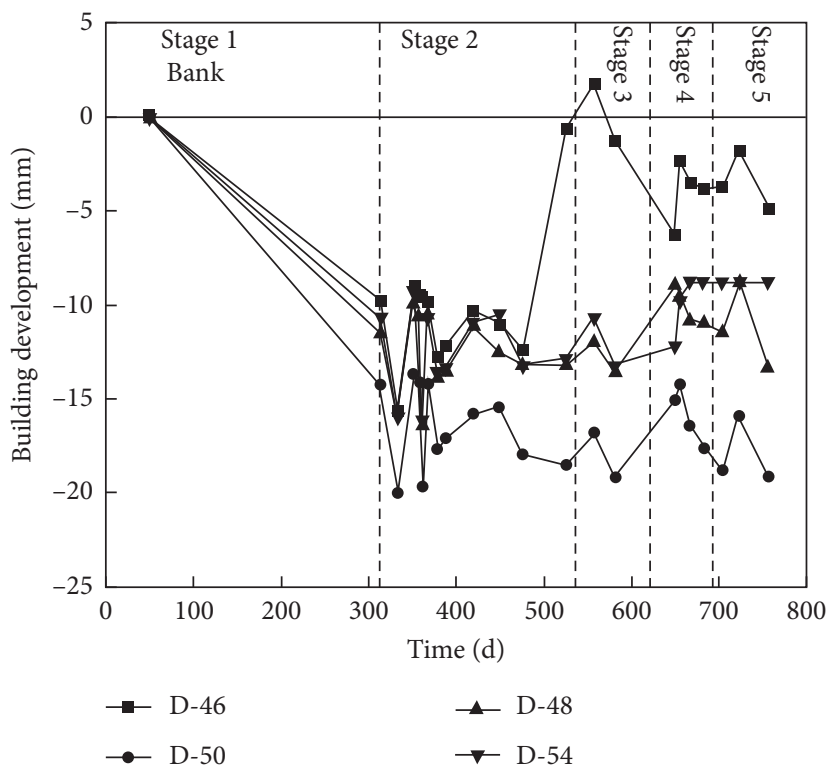

(b)

FIgURE 9: Continued. 


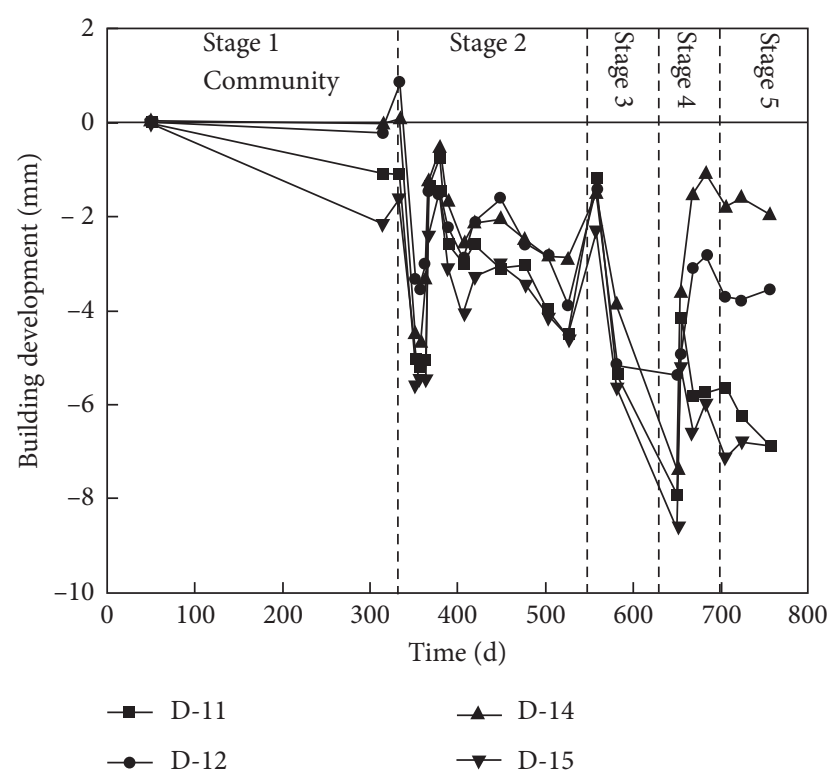

(c)

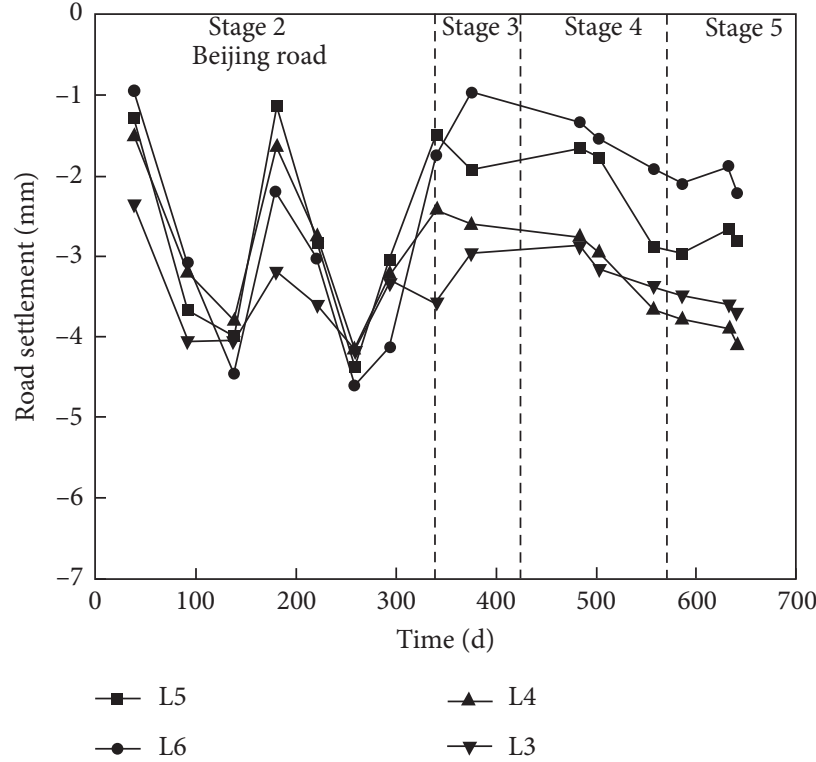

(d)

Figure 9: Settlement of (a) apartment; (b) bank; (c) community; and (d) Beijing road.

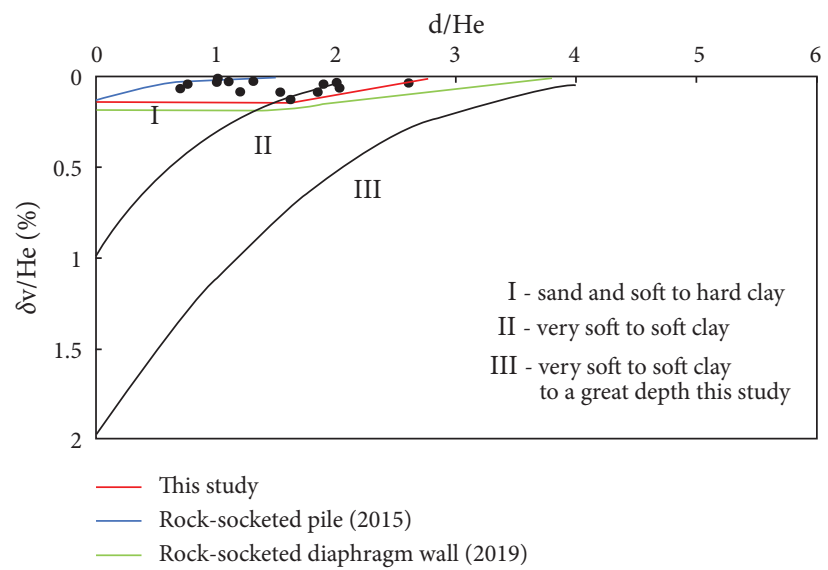

Figure 10: Observed building settlement profiles versus those predicted by empirical methods: the relationship between $\left(\delta_{v} / H_{e}\right)$ and $\left(d / H_{e}\right)$.

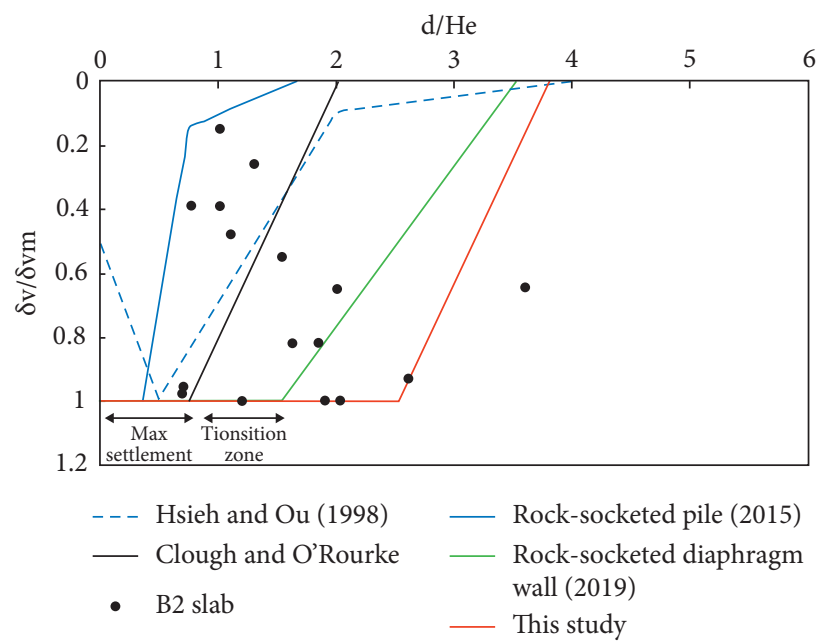

FIGURE 11: Observed building settlement profiles versus those predicted by empirical methods: the relationship between $\left(\delta_{v} / \delta_{v m}\right)$ and $\left(d / H_{e}\right)$. 


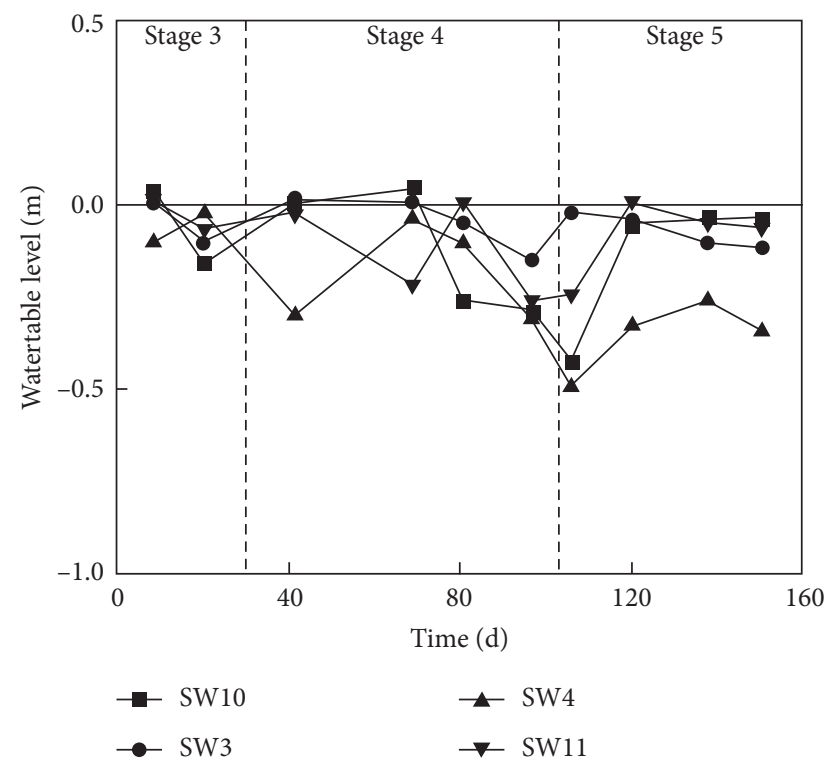

Figure 12: Variation of groundwater table levels during excavation.

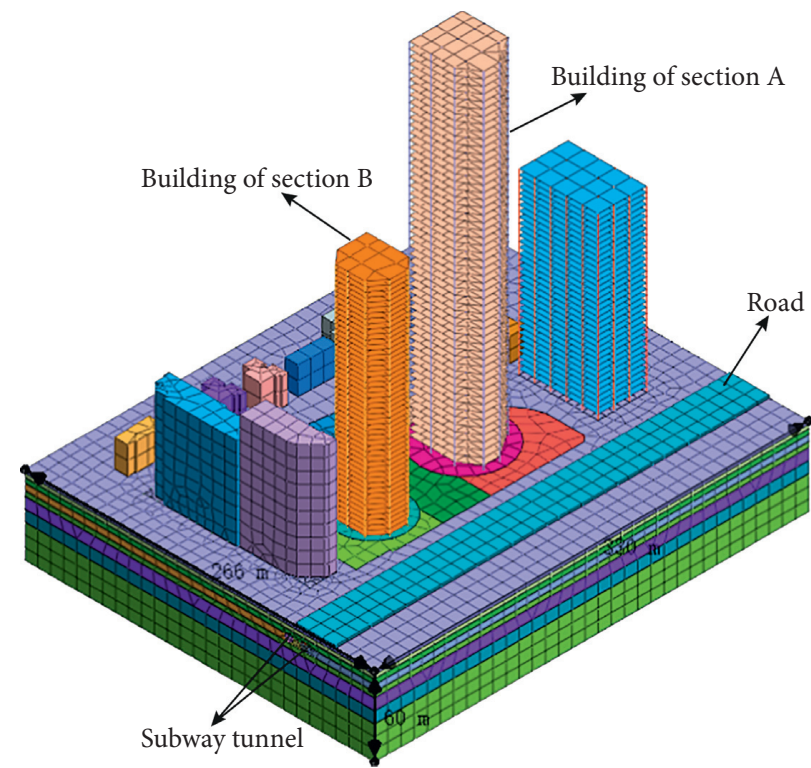

Figure 13: GTS NX integral model.

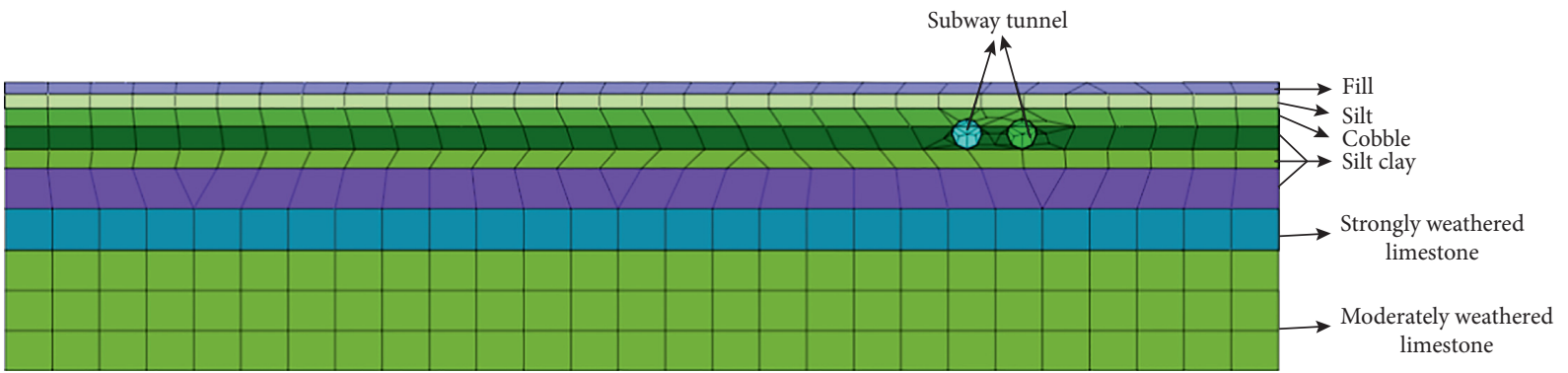

FIgURE 14: Soil layer distribution. 
TABLe 3: Physical and mechanical parameters of the materials.

\begin{tabular}{lcccc}
\hline Materials & Thickness, $H(\mathrm{~m})$ & Elastic modulus, $E(\mathrm{MPa})$ & Poisson ratio, $\mu$ & $\mathrm{Unit}$ weight, $\gamma\left(\mathrm{kN} / \mathrm{m}^{3}\right)$ \\
\hline Tunnel lining & 0.35 & 34.5 & 0.2 & 26.5 \\
Supporting structure & - & 30.0 & 0.2 & 25.0 \\
Slab & - & 31.5 & 0.2 & 25.5 \\
\hline
\end{tabular}

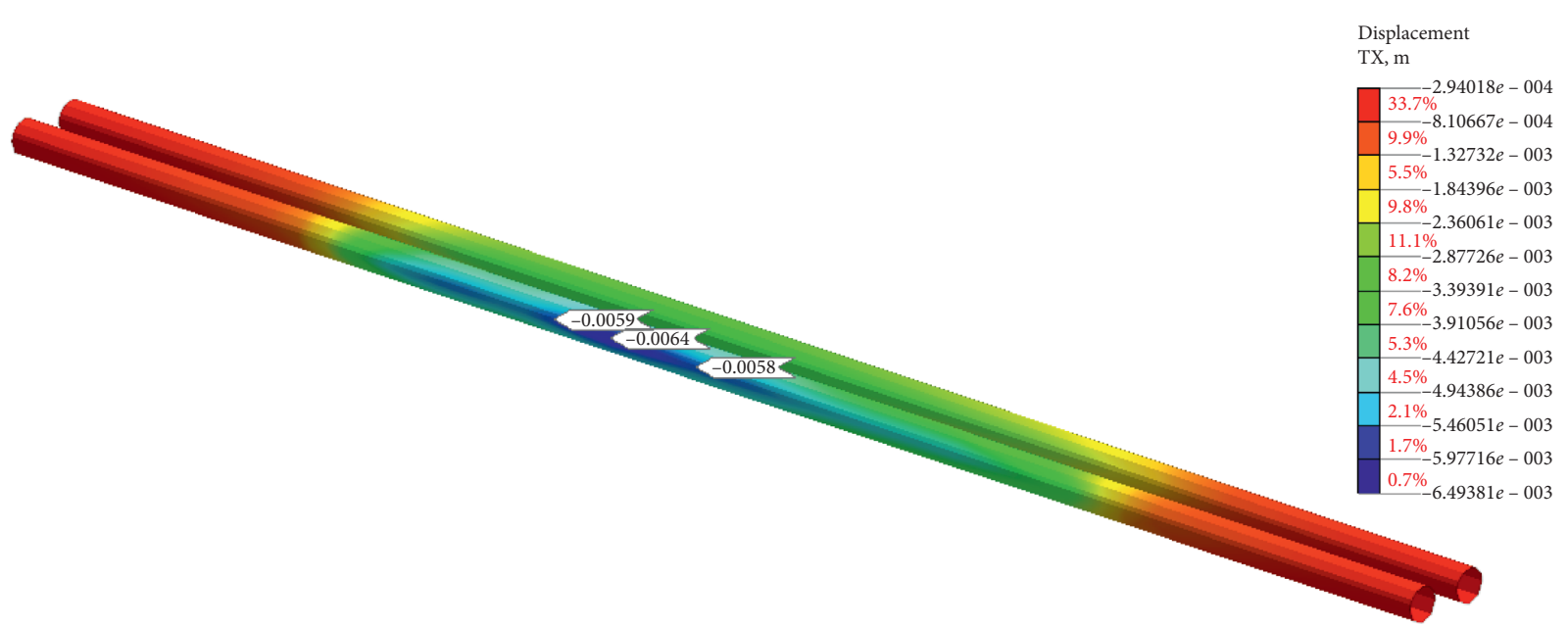

(a)

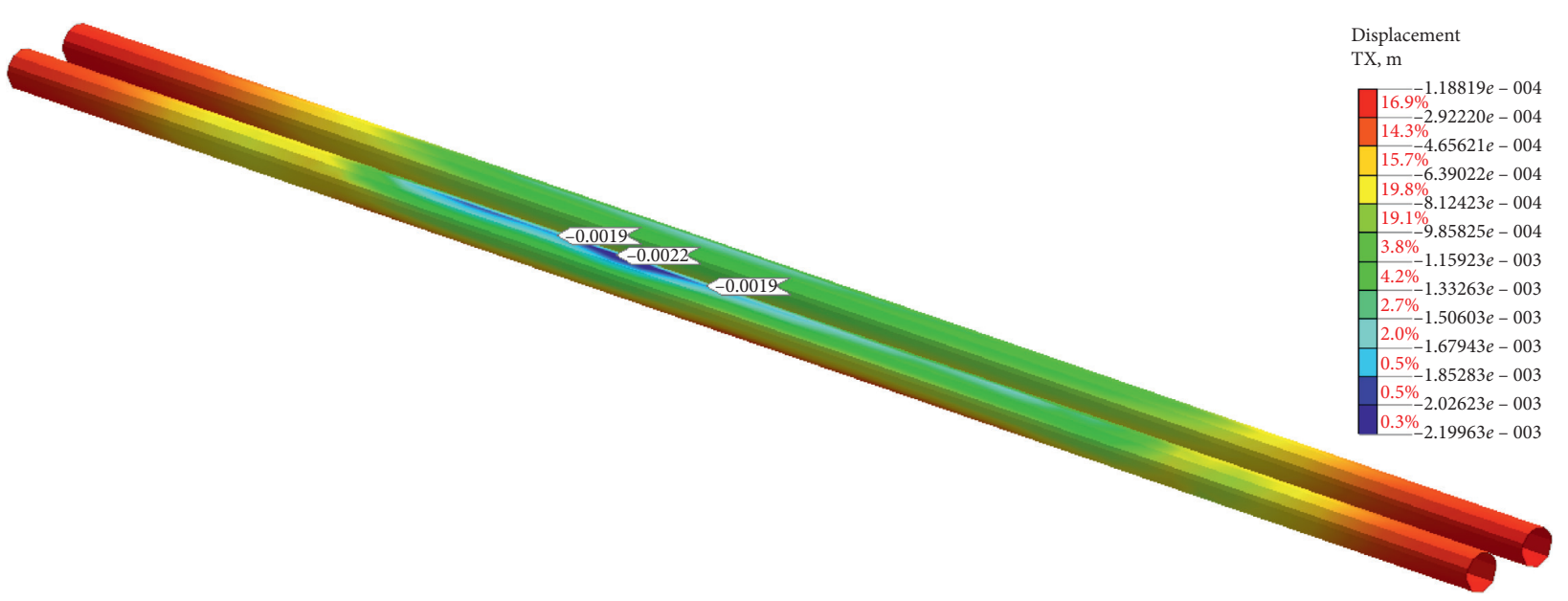

(b)

FIGURE 15: Maximum deformation position of the tunnel: (a) horizontal direction; (b) vertical direction.

analyze the foundation's construction without considering groundwater's influence. According to the simulation results, the foundation pit excavation on the surrounding subway tunnel's displacement and internal force is analyzed.

\subsection{Three-Dimensional Finite Element Calculation Model.} According to the actual situation and the scope of the pit's excavation, the model size is $330 \mathrm{~m} \times 266 \mathrm{~m} \times 60 \mathrm{~m}$ (as shown in Figure 13). The model simplifies the surrounding environment and soil layers. The distribution of each soil layer in the model is shown in Figure 14. The soil adopts the Mohr-Coulomb criterion, and the concrete structure adopts the elastic criterion. The beam element is used to simulate the column pile, and the slab element is used to simulate the diaphragm wall, the slab, and the tunnel lining. The parameters used for the soil in the calculation and analysis are shown in Table 2, and the physical and mechanical parameters of the foundation pit supporting structure and tunnel lining are shown in Table 3.

\subsection{Deformation of Subway Tunnel Caused by Foundation Pit} Excavation. During excavation, with the diaphragm wall's deformation and the uplift of the soil at the bottom of the pit, the subway tunnel adjacent to the pit will produce horizontal and vertical displacement. The maximum deformation is located at the center of the long side of the pit (as shown in Figures 15(a) and 15(b)). Figure 16 is the maximum value of the tunnel deformation computed and measured during 


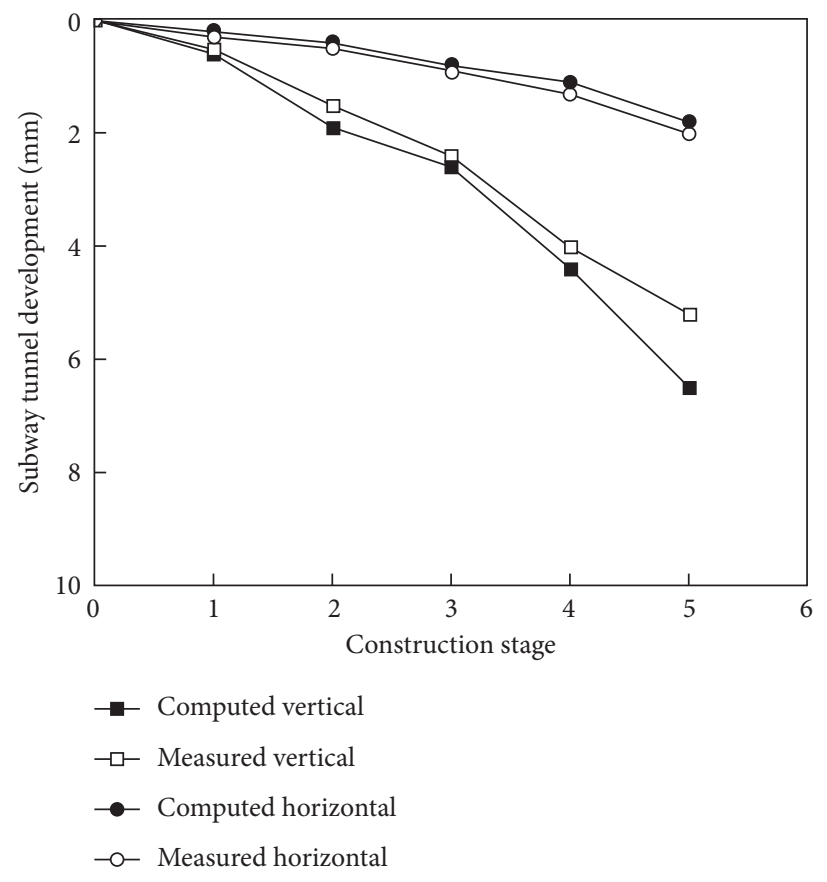

Figure 16: Maximum deformation of the subway tunnel.

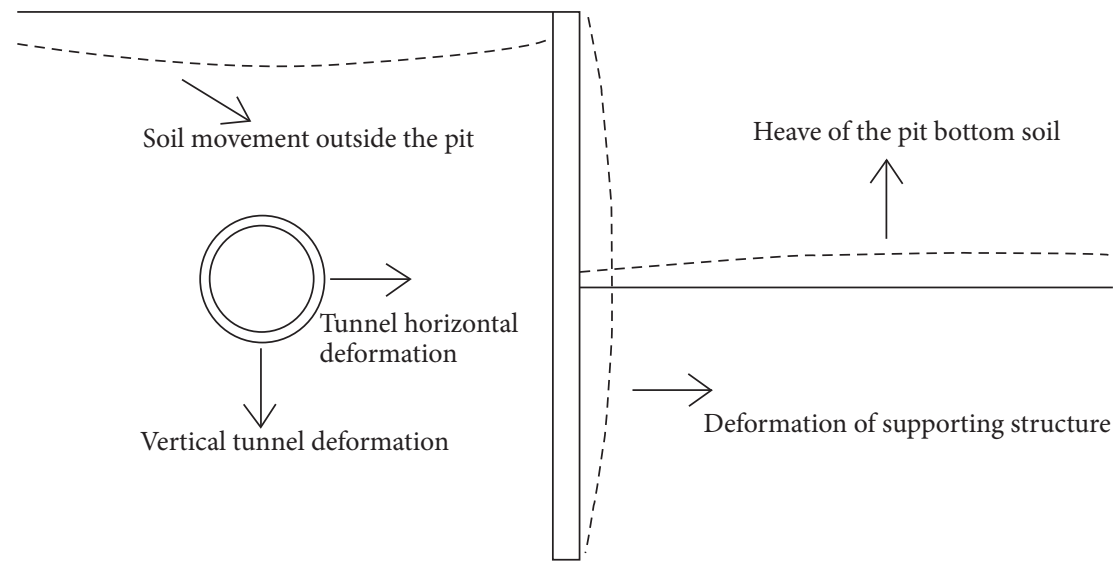

Figure 17: Diagram of deformation of subway tunnel [30].

construction. Overall, the displacements of subway tunnels caused by the construction of pit are not very significant. The measured maximum horizontal displacement is $5.2 \mathrm{~mm}$, the vertical deformation is $2 \mathrm{~mm}$, and the computed results are $6.5 \mathrm{~mm}$ and $1.8 \mathrm{~mm}$, respectively. Due to stress release, the soil at the bottom of the pit rises uplift, the retaining structure of the foundation pit deforms laterally, and the ground around the pit subsides, which leads to the deformation of the subway tunnel outside the pit during excavation [30] (as shown in Figure 17).
4.3. Changes in Internal Forces of Subway Tunnel Caused by Foundation Pit Excavation. Figures 18 and 19 show the axial force and bending moment change at the tunnel's maximum deformation point during excavation. Consistent with the displacement change, the axial force and bending moment are minor changes during the construction stages 1 to 3 . The axial force fluctuates during the current construction stage. However, compared with the initial construction period, the axial force on the subway tunnel increased at stage 5, and the horizontal axial force 


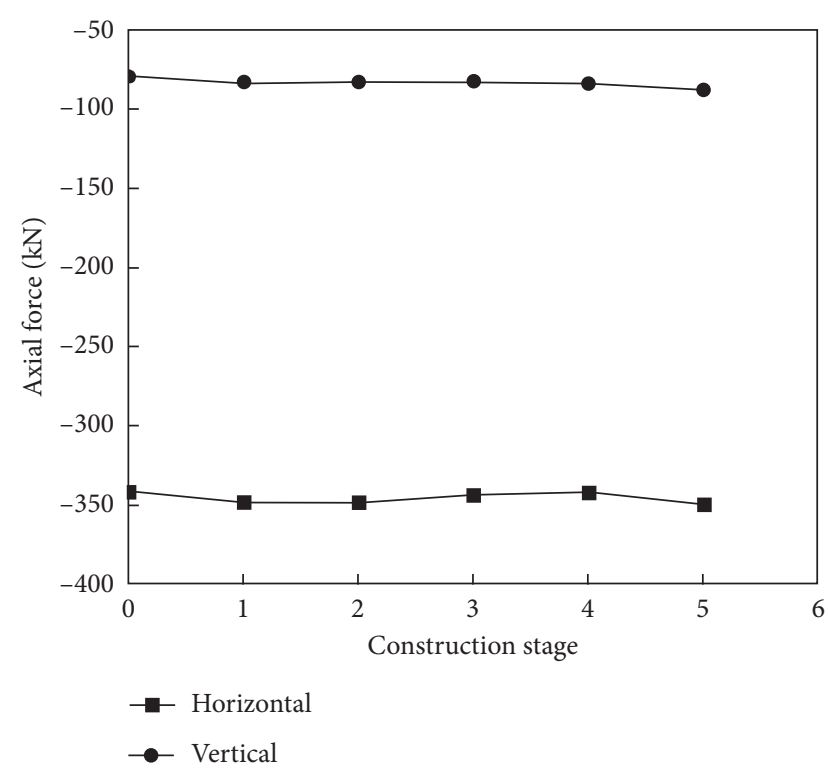

FIgURE 18: Axial force change.

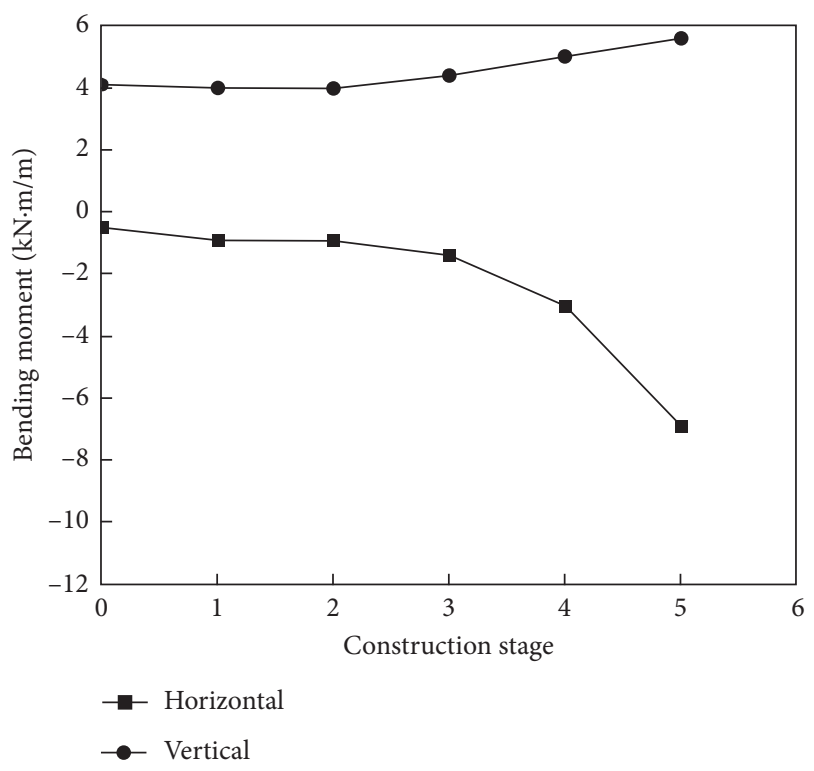

Figure 19: Bending moment change.

increased from $-341.3 \mathrm{kN}$ to $-348.9 \mathrm{kN}$, and the vertical axial force increased from $-79 \mathrm{kN}$ to $-87.8 \mathrm{kN}$. Due to excavation, the positive bending moment (the vertical direction) and negative bending moment (the horizontal direction) of the subway tunnel increased by $1.5 \mathrm{kN} \cdot \mathrm{m} / \mathrm{m}$ and $6.4 \mathrm{kN} \cdot \mathrm{m} / \mathrm{m}$, respectively.

\section{Conclusions}

Based on the analyses of the field data, the following significant findings were obtained:

(1) The relationship between the measured maximum wall deflection, $\delta_{h m}$, and excavation depth, $H$, in this study is $\delta_{h m}=0.06 \% H \sim 0.27 \% H$, which is quite different compared with the relationship of soft-soil foundation pit $\delta_{h m}=0.02 \% H \sim 1.2 \% H$, and compared with the normalized curve of the rock-socketed supported foundation pit, $\delta_{h m}=0.01 \% H \sim 0.45 \% H$ (rock-socketed pile), and $\delta_{h m}=0.031 \% H \sim 0.129 \% H \quad$ (rock-socketed diaphragm wall) is closer.

(2) The relationship between the maximum settlement of column $\left(\delta_{p}\right)$ and excavation depth $(H)$ is $\delta_{p}=-0.09 \% \sim 0.04 \% H$. The maximum distortion between the diaphragm wall and the column is less than $1 / 500$ of the limit range proposed by Bjerrum.

(3) Due to the area, deformation of supporting structure, and the surrounding environment, the building settlements in this study showed a typical concave profile. The maximum ground settlements did not occur right behind the diaphragm wall, but in the zones around $2.7 H_{e}$, and the influence zone extended beyond $3.8 \mathrm{H}_{e}$.

(4) The foundation pit's excavation leads to the maximum vertical settlement of $2 \mathrm{~mm}$ and maximum horizontal displacement of $5.2 \mathrm{~mm}$ in the subway tunnel. The maximum change of axial force and bending moment is $8.8 \mathrm{kN}$ (the vertical direction) and $6.4 \mathrm{kN} \cdot \mathrm{m} / \mathrm{m}$ (the horizontal direction).

\section{Data Availability}

The data used to support the findings of this study are included with in the article.

\section{Conflicts of Interest}

The authors declare that they have no conflicts of interest.

\section{Acknowledgments}

This article was supported by the National Natural Science Foundation of China (nos. 51568030, 51768027, and 52068039) and the Yunnan Basic Research Key Project (no. 2018BC013).

\section{References}

[1] Q. G. Fan and X. H. Zhao, "Theory and calculation of reverse practice in deep foundation pit engineering," Chinese Journal of Rock and Soil Mechanics, vol. 12, pp. 2169-2176, 2006.

[2] Y. Tan and M. Li, "Measured performance of a $26 \mathrm{~m}$ deep topdown excavation in downtown Shanghai," Canadian Geotechnical Journal, vol. 48, no. 5, pp. 704-719, 2011.

[3] Y. Tan and D. Wang, "Characteristics of a large-scale deep foundation pit excavated by the central-island technique in Shanghai soft clay. II: top-down construction of the peripheral rectangular pit," Journal of Geotechnical and Geoenvironmental Engineering, vol. 139, no. 11, pp. 1894-1910, 2013.

[4] G. B. Liu, R. J. Jiang, C. W. W. Ng, and Y. Hong, "Deformation characteristics of a $38 \mathrm{~m}$ deep excavation in soft clay," $\mathrm{Ca}$ nadian Geotechnical Journal, vol. 48, no. 12, pp. 1817-1828, 2011. 
[5] Z. H. Xu, J. H. Wang, and W. D. Wang, "Deformation behavior of diaphragm walls in deep excavations in Shanghai," China Civil Engineering Journal, vol. 41, no. 8, pp. 81-86, 2008.

[6] N. Hwang Richard and M. Za-Chieh, "Performance of floor slabs in excavations using top-down method of construction and correction of inclinometer reading," Journal of GeoEngineering, vol. 2, no. 3, pp. 111-121, 2007.

[7] C.-Y. Ou, P.-G. Hsieh, and D.-C. Chiou, "Characteristics of ground surface settlement during excavation," Canadian Geotechnical Journal, vol. 30, no. 5, pp. 758-767, 1993.

[8] I. H. Wong, T. Y. Poh, and H. L. Chuah, "Performance of excavations for depressed expressway in Singapore," Journal of Geotechnical and Geoenvironmental Engineering, vol. 123, no. 7, pp. 617-625, 1997.

[9] E. H. Y. Leung and C. W. W. Ng, "Wall and ground movements associated with deep excavations supported by cast in situ wall in mixed ground conditions," Journal of Geotechnical and Geoenvironmental Engineering, vol. 133, no. 2, pp. 129-143, 2007.

[10] B. R. Peck, "Deep excavation and tunneling in soft ground," in Proceedings of the 7th International Conference on Soil Mechanics and Foundation Engineering, pp. 225-290, Mexico City, Mexico, August 1969.

[11] P.-G. Hsieh and C.-Y. Ou, "Shape of ground surface settlement profiles caused by excavation," Canadian Geotechnical Journal, vol. 35, no. 6, pp. 1004-1017, 1998.

[12] W. G. Clough and T. D. O’Rourke, "Construction induced movements of in-situ walls," in Proceedings of the ASCE Conference on Design and Performance of Earth Retaining Structures Special Publication No. 25, pp. 439-470, Ithaca, NY, USA, June 1990.

[13] L. C. Kuang, "Influence of deep foundation Pit construction on subway tunnel," Chinese Journal of Geotechnical Engineering, vol. 3, pp. 284-288, 2000.

[14] C.-T. Chang, C.-W. Sun, S. W. Duann, and R. N. Hwang, "Response of a taipei rapid transit system (TRTS) tunnel to adjacent excavation," Tunnelling and Underground Space Technology, vol. 16, no. 3, pp. 151-158, 2001.

[15] Z. Jiang and Y. Zhang, "Calculation of influence on longitudinal deformation of adjacent tunnels due to excavation," Chinese Journal of Architectural and Environmental Engineering, vol. 35, pp. 7-39, 2013.

[16] Z. G. Zhang, M. S. Huang, and W. D. Wang, "Influence of adjacent excavation on existing soft soil tunnel," Chinese Journal of Rock and Soil Mechanics, vol. 5, pp. 1373-1380, 2009.

[17] J.-F. Zhang, J.-J. Chen, J.-H. Wang, and Y.-F. Zhu, "Prediction of tunnel displacement induced by adjacent excavation in soft soil," Tunnelling and Underground Space Technology, vol. 36, pp. 24-33, 2013.

[18] H. T. Ai, G. Y. Gao, and S. J. Feng, "Deformation analysis of deep foundation pit near subway tunnel," Chinese Journal of Rock Mechanics and Engineering, vol. 2, pp. 5485-5489, 2005.

[19] K. J. Qi, X. D. Wang, G. Jiang, Y. S. Chang, and Y. D. Chen, "Analysis of deep foundation pit excavation near subway tunnel," Tunnelling and Underground Space Technology, vol. 36, pp. 24-33, 2013.

[20] Z. F. Hu, Z. Q. Yue, J. Zhou, and L. G. Tham, "Design and construction of a deep excavation in soft soils adjacent to the Shanghai Metro tunnels," Canadian Geotechnical Journal, vol. 5, no. 40, pp. 933-948, 2003.

[21] K. Lo and J. Ramsay, "The effect of construction on existing subway tunnels-a case study from Torontow," Tunnelling and
Underground Space Technology, vol. 6, no. 3, pp. 287-297, 1991.

[22] W. D. Wang, J. Shen, Q. P. Weng, and J. B. Wu, "Analysis and countermeasures of influence of excavation on adjacent tunnels," Chinese Journal of Geotechnical Engineering, vol. 28, pp. 1340-1345, 2006.

[23] Z. Jiang, Y. Su, and J. Lian, "Deformation of an existing tunnel adjacent to an excavation in progress," Chinese Journal of Geotechnical Engineering, vol. 19, pp. 3987-3997, 2014.

[24] W. D. Wang, J. B. Wu, and Q. P. Weng, "Numerical simulation of the influence of foundation pit excavation and unloading on subway tunnels," Chinese Journal of Rock and Soil Mechanics, vol. 2, pp. 251-255, 2004.

[25] J. H. Li and W. Xu, "Mechanical performance study and design suggestion of rock-socketed diaphragm wall," Chinese Journal of Journal of Underground Space and Engineering, vol. 5, pp. 177-180, 2007.

[26] M. H. Huang and X. L. Chen, "Performance analysis of deep foundation pit rock-socketed Support in Sand-rock composite formation in Nanchang area," Chinese Journal of Science and Technology, vol. 13, no. 22, pp. 103-111, 2018.

[27] C. Tang and S. M. Liao, "Field measurement and analysis of deformation behavior of deep foundation pit in soil-rock composite stratum," in Proceedings of the China Civil Engineering Society Annual Academic Conference, Chengdu, China, October 2019.

[28] L. Bjerrum, "Allowable settlement of structures," in Proceedings of the Third European Conference on Soil Mechanics and Foundation Engineering, pp. 135-137, Weisbaden, Germany, September 1963.

[29] J. P. Cai, "Study on surface deformation law of underground deep foundation pit in soil-rock combination stratum," China \& Foreign Highway, vol. 35, no. 4, pp. 23-29, 2015.

[30] X. B. Wang and J. Jia, "Influence analysis and control measures of deep foundation pit excavation on existing metro tunnel," Chinese Journal of Research on Urban Road Traffic, vol. 28, pp. 52-57, 2009. 